\title{
Grounded theory: building a middle-range theory in nursing
}

\author{
Grounded theory: a construção de uma teoria de médio-alcance em enfermagem
}

\author{
Maria João Fernandes \\ Escola Superior de Saúde Ribeiro Sanches - ERISA, Lisboa, Portugal \\ Email: maria.fernandes@erisa.pt
}

\begin{abstract}
The development of nursing as a discipline results from a boom of investigations underway for nearly a century, and of the construction of theories that have arisen during the 1950's, with greater relevance since the 1960's. Giving continuation to the production of knowledge in nursing and seeking to contribute to the increase in the number of explanatory theories of the functional content of nurses, there is interest in answering the question: how can a middle-range theory in nursing be built that explains the nurse-elderly interaction in a successful aging process? As well, we address the goal of describing the process of building a middle-range theory in nursing.

Middle-range theory refers to a qualitative paradigm study of inductive thinking, developed in the context of primary health care. The information was collected through participant observation and interviews. Method of analysis grounded theory by Corbin and Strauss(1) was followed, utilizing the triangulation of data and theoretical sampling.

Grounded theory has become a method of analysis which facilitates the understanding and explanation of the phenomenon under study. By making clear the nature and process of the nurse-elderly interaction in the selected context and within the context of successful aging, a middle-range theory proposal emerged.
\end{abstract}

Keywords: Stroke, Respiratory Muscle Strength, Maximum Respiratory Pressure and Respiratory Muscle Training.

\section{Resumo}

O objetivo deste estudo foi realizar uma revisão de literatura sobre as principais alterações que ocorrem no sistema respiratório após o Acidente Vascular Cerebral (AVC) e também sobre os efeitos de treino muscular respiratório nestes pacientes. A metodologia adotada foi a pesquisa de artigos através das bases de dados electrónicas (Pubmed, Scielo e Pedro) em língua portuguesa e inglesa relacionando os temas: alterações do sistema respiratório e métodos de avaliação e reabilitação da força muscular respiratória em indivíduos acometidos pelo AVC. Existe evidência científica de que indivíduos acometidos pelo AVC podem apresentar diminuição da força muscular inspiratória e expiratória. Estudos sugerem que o treino muscular respiratório, através de carga limiar, pode trazer benefícios quanto a melhora da função respiratória e da força dos músculos respiratórios. Porém, mais estudos devem ser realizados para o aprofundamento do conhecimento sobre os benefícios e efeitos a longo prazo da reabilitação respiratória em pacientes com AVC.

Palavras-chave: Grounded theory, middle-range theory, nursing. 


\section{Introduction}

The nursing theories gather conceptual constructs from research, providing guidelines for professional practice $^{(2,3,4,5,6,7)}$.

Overall, theories are constructed to obtain sets of logically intertwined propositions, from which can be derived various empirical uniformities that show the nature of the phenomenon. They provide consistent and appropriate solutions to the problems preventing or resolving issues of conceptual forum. Cognitive control theory itself is reflected in the determination of responses to empirical and conceptual issues ${ }^{(8,2,9)}$.

In particular, a middle-range theory approaches and guides the object under study: behavior, organization and change, facilitating the clarification of what is observed, describing it with sorting and detail. The phenomenon or concept tends to be transversal to various fields of study, although not generalized. Thus, the middle-range theories offer ideas with the intention of being easily understood and followed, providing explanatory models for practice ${ }^{(10,2,3,9,6,7)}$.

Until Flood ${ }^{(11)}$, no theory in gerontological nursing and a successful aging context offered specific guidelines for caring for senior adults, or was part of the successful aging phenomenon ${ }^{(12,13,11,14)}$.

In parallel, the grounded theory has been commonly used within the nursing field to produce theories that explain the interaction between nurses and individuals in painful processes, suffering, and at the end of life. In Portugal, the theories of Cepas ${ }^{(15)}$ Lopes $^{(16)}$ and Veiga ${ }^{(17)}$ are known. This theoretical construction method may also be feasible in the study of phenomena unrelated to the pain and suffering.

It was determined in a preliminary/exploratory/pilot study ${ }^{(18)}$, before the construction of the theory, that it was also necessary to produce knowledge in phenomenon centered on persons in life processes with health or disease, with or without estimate of time of death, but perhaps with life purposes and successful aging.

The grounded theory is a method used to generate constant theory through constant comparative analysis of data obtained in systematic natural contex ts ${ }^{(1,19,20,12,13,21,22,23,15,24,25)}$. This method comes from the theory of symbolic interaction ${ }^{(26)}$, which arose in the Chicago School with Mead (1863-1931) and was especially developed by Herbert Blumer (1900-1987). The symbolic interaction, based on the study of human behavior and life of human groups, searches for the meaning that events have on people and the selection of symbols those same people use to represent them ${ }^{(20)}$. Thus, the grounded theory ${ }^{(1)}$ provides a methodological

\section{Introdução}

As teorias de enfermagem reúnem constructo conceptual, resultante da investigação, propiciando entre si orientações para o exercício profissional ${ }^{(2,3,4,5,6,7)}$.

No geral, constroem-se teorias para se obter conjuntos de proposições logicamente entrelaçadas, dos quais podem derivar várias uniformidades empíricas que evidenciam a natureza do fenómeno. Elas fornecem soluções coerentes e adequadas aos problemas evitando ou resolvendo questões do foro conceptual. O controlo cognitivo da própria teoria traduz-se na determinação de respostas a quaisquer questões empíricas e conceptuais ${ }^{(8,2,9)}$.

Concretamente, uma teoria de médio-alcance ao tornar-se a intermédia face ao seu nível de abstracção, aproxima e guia para o objeto em estudo: comportamento, organização e mudança, facilitando a explicitação do que é observado, descrevendo-o com ordenação e pormenor. $\mathrm{O}$ fenómeno ou conceito tende a ser transversal a vários campos de estudo, apesar de não ser generalizável. Assim, as teorias de médio-alcance oferecem ideias com a intenção de serem facilmente compreendidas e acompanhadas, constituindo modelos explicativos para o exercício ${ }^{(10,2,3,9,6,7)}$

Em enfermagem gerontológica e num contexto de envelhecimento bem-sucedido, até surgir Flood $^{(11)}$, estava identificado que nenhuma teoria oferecia linhas orientadoras específicas para cuidar adultos seniores, nem integrava o fenómeno envelhecimento bem-suce$\operatorname{dido}^{(12,13,11,14)}$

Paralelamente, a grounded theory tem sido comummente utilizada pela enfermagem para produzir teorias explicativas da interação entre enfermeiros e pessoas em processo de dor, sofrimento e fim de vida. Só em Portugal são conhecidas as teorias de Cepas ${ }^{(15)}$, Lopes $^{(16)}$ e Veiga ${ }^{(17)}$. Mas será que este método de construção teórica não poderá ser viável no estudo de fenómenos alheios à dor e sofrimento?

Foi certificado, em estudo preliminar/exploratório/piloto ${ }^{(18)}$, anterior à construção da teoria, que era igualmente necessário produzir conhecimento em fenómenos centrados nas pessoas em processo de vida com saúde ou doença, com ou sem previsão do momento da morte, mas porventura com propósitos de vida e de envelhecimento bem-sucedido.

A grounded theory é um método utilizado para gerar teoria a partir da análise comparativa constante dos dados sistematicamente obtidos em contextos naturais ${ }^{(1}$ $, 19,20,12,13,21,22,23,15,24,25)$. Este método tem origem na teoria do interacionismo simbólico ${ }^{(26)}$, a qual nasce na Escola de Chicago com Mead (1863-1931) e é desenvolvida 
approach, which seems to be a facilitator for the theoretical construction, in order to obtain the answers to the question of research and formulated objectives: determining how the nurse interacts with the elderly person so that he can use his essence (his individual life potential), showing protective and promoting behaviors in successful aging; identifying aging successful elements from the perspective of the elderly person and nurse; and understanding the nature and method of the elderly person-nurse interaction that leads to the use of protective behaviors and successful aging promotion. Additionally, the grounded theory is appropriate as the item under study consists of a process, of inter-subjective content, and of a search of symbolic meanings of groups of people in social interaction.

\section{Material and methods}

The issue of the research, the guiding question of the study and the objectives outlined converged to the constant comparative data analysis. The grounded theory, according to Corbin and Strauss ${ }^{(1)}$, has become the method that focuses on the successive meeting between researcher and the context (elderly person-nurse) interaction. The social group, as actors, developed their scene in primary health care. Participants who believed it is possible to age well. Chosen environments served this purpose.

As this is an explanatory study, the research positioned itself in the naturalistic paradigm, qualitative in the line of symbolic interaction, imbued by inductive thinking. The presentation stages of the investigational route follow.

Step 1 - After research design, discussion of technical literature review, and validated by pilot/ preliminary study, the theory building process was initiated. Knowledge of the context in which the data collection would happen and of the viable spaces of the definitive study kept happening. The investigator began to closely monitor the possible actors (participants).

Step 2 - Following a selection process of cases through theoretical sampling, integrating individuals and groups according to the expectations of them in relation to ideas that could provide for the construction of the especialmente por Herbert Blumer (1900-1987). O interacionismo simbólico, estando assente no estudo do comportamento humano e da vida de grupos humanos, procura o significado que os eventos têm para as pessoas e quais os símbolos, que essas mesmas pessoas utilizam para os representarem ${ }^{(20)}$.

Desta forma, a grounded theory ${ }^{(1)}$ oferece um caminho metodológico, que parece ser facilitador tanto para a construção teórica, como para a obtenção das respostas à pergunta de investigação e aos objetivos formulados: como é que o enfermeiro interage com a pessoa idosa para que esta utilize a sua essência (o seu potencial individual de vida) evidenciando comportamentos protetores e promotores de envelhecimento bem-sucedido?; identificar elementos do envelhecimento bem-sucedido na perspetiva da pessoa idosa e do enfermeiro; e compreender a natureza e o processo da interação enfermeiro-pessoa idosa que conduz à utilização de comportamentos protetores e promotores de envelhecimento bem-sucedido. E também porque o assunto em estudo se tratar de um processo, de teor intersubjetivo e de procura explicativa de significados simbólicos de grupos de pessoas em interação social.

\section{Material e métodos}

A problemática da investigação, a questão norteadora do estudo e os objetivos delineados confluíram para a análise comparativa constante de dados. A grounded theory, segundo Corbin e Strauss ${ }^{(1)}$, tornou-se o método que privilegiou o sucessivo encontro entre investigador e o contexto de interação enfermeiro-pessoa idosa. O grupo social, enquanto atores, desenvolveu a sua cena em cuidados de saúde primários. Participantes acreditavam ser possível envelhecer de forma bem-sucedida. Ambientes escolhidos proporcionavam esse propósito. Sendo o estudo explicativo, a investigação posicionou-se no paradigma naturalista, qualitativo na linha do interacionismo simbólico, imbuída pelo pensamento indutivo. Segue-se a apresentação as etapas do percurso investigacional.

$1^{a}$ etapa - Após desenho da investigação argumentado pela revisão da literatura técnica e validado por estudo piloto/preliminar deu-se início ao processo de construção da teoria. Foi-se conhecendo o contexto onde a recolha de dados iria acontecer e os espaços viáveis ao estudo definitivo. O investigador foi passando a estar próximo dos possíveis atores (participantes).

$2^{\mathrm{a}}$ etapa - Seguindo um processo de seleção de casos através de amostragem teórica, foram-se integrando indivíduos e grupos de acordo com as expetativas que se tinha deles relativamente às ideias que podiam oferecer 
theory was made. With the appropriate data, knowledge continued to emerge, which led the researcher to the selection of new subjects for groups and subgroups. The sample consisted of a continuous process subjected to interspersed theoretical criteria and result of data analysis. The "theoretical saturation" occurred when no additional data that could deepen properties and dimensions was observed. para a construção da teoria. Mediante os dados que iam sendo apropriados, foi emergindo um conhecimento, através do qual conduziu o investigador à seleção de novos sujeitos, grupos e subgrupos. A amostra constituiu um processo contínuo subordinado a critérios teóricos intercalada e decorrente da análise de dados. A "saturação teórica" surgiu quando deixaram de aparecer dados adicionais que pudessem aprofundar propriedades e dimensões.

Table 1 / Table 1 - Developed Fieldwork /trabalho de campo desenvolvido

\begin{tabular}{|c|c|c|}
\hline $\begin{array}{l}\text { Study } \\
\text { /Estudo }\end{array}$ & $\begin{array}{l}\text { Time intervals/ } \\
\text { Intervalos de tempo }\end{array}$ & Data Collection/Recolha de dados \\
\hline \multirow{2}{*}{$\begin{array}{l}\text { Preliminary } \\
\text { /preliminar }\end{array}$} & March /março 2007 & 3 Life Stories/histórias de vida \\
\hline & $\begin{array}{l}\text { November/novembro } \\
2007\end{array}$ & 3 Focus groups/focus groups 4 - 5 participants/participantes \\
\hline \multirow[t]{5}{*}{$\begin{array}{l}\text { Definitive } \\
\text { /definitivo }\end{array}$} & $\begin{array}{l}\text { May-June/ } \\
\text { maio-junho } \\
2008\end{array}$ & $\begin{array}{l}4 \text { participants observations Center Day SJP/observações participantes em } \\
\text { Centro de Dia } \\
\text { Interaction enf }{ }^{\mathrm{a}} \mathrm{D} \text {, enf }{ }^{\mathrm{a}} \mathrm{E} \text { - } 6-12 \text { elderly - each observation, the } 66 \text { to } 88 \text { years } \\
\text { (individual assistance) with informal interviews / Interação enf }{ }^{\mathrm{a}} \mathrm{D} \text {, enf }{ }^{\mathrm{a}} \mathrm{E}-6 \\
\text { a } 12 \text { pessoas idosas/cada observação, dos } 66 \text { aos } 88 \text { anos (atendimentos } \\
\text { individuais) com entrevistas informais } \\
3 \text { participants Observations Day Centre E /observações participantes no } \\
\text { Centro de Dia E } \\
\text { Enf }{ }^{\mathrm{a}} \mathrm{D} \text { interaction - 6-14 elderly - each observation of } 68 \text { to } 91 \text { years } \\
\text { (individual assistance) with informal interviews / Interação enf }{ }^{\mathrm{a}} \mathrm{D} \text { - } 6 \text { a } 14 \\
\text { pessoas idosas-cada observação dos } 68 \text { aos } 91 \text { anos (atendimentos } \\
\text { individuais) com entrevistas informais } \\
1 \text { participant observation in Health Center in diabetes management } \\
\text { consulting / Observação participante em Centro de Saúde em consulta de } \\
\text { controlo da diabetes } \\
1 \text { participant observation in Health Center in care in treatment room / } \\
\text { Observação participante em Centro de Saúde em atendimento em sala de } \\
\text { tratamentos }\end{array}$ \\
\hline & July / julho 2008 & Informal interviews enf $f^{a} \mathrm{~A}$ and enf ${ }^{\mathrm{a}} \mathrm{B} /$ entrevistas informais enf $\mathrm{f}^{\mathrm{a}} \mathrm{A}$ e enf $\mathrm{f}^{\mathrm{a}} \mathrm{B}$ \\
\hline & $\begin{array}{l}\text { November } 2008 \text { to } \\
\text { March } 2009 \text { / } \\
\text { Novembro } 2008 \text { a } \\
\text { Março } 2009\end{array}$ & $\begin{array}{l}21 \text { participants observations Health Center group activities / Observações } \\
\text { participantes em atividades de grupo Centro de Saúde } \\
\text { Interaction enf }{ }^{\mathrm{a}} \mathrm{A}, \mathrm{B} \text { and } \mathrm{C}-12 \text { to } 32 \text { elderly each, years to } 86 \text {. / Interação } \\
\text { enf }^{\mathrm{a}} \mathrm{A}, \mathrm{B} \text { e } \mathrm{C}-12 \text { a } 32 \text { pessoas idosas cada, até } 86 \text { anos } \\
3 \text { formal Interviews semi-structured and in-depth } \\
\text { / } 3 \text { entrevistas formais semi-estruturadas e em profundidade } \\
17 \text { Informal interviews / entrevistas informais }\end{array}$ \\
\hline & $\begin{array}{l}\text { March and April } 200 \\
\text { /Março e abril } 2009\end{array}$ & $\begin{array}{l}\text { Formal interviews (semi-structured) enf } f^{\mathrm{a}} \mathrm{B} \text {, enf } \mathrm{f}^{\mathrm{a}} \mathrm{C} \text { and enf } \mathrm{f}^{\mathrm{a}} \mathrm{D}-24 \text { to } 65 \\
\text { years } \\
\text { Entrevistas formais (semi-estruturadas) enf } \mathrm{B} \text {, enf }{ }^{\mathrm{a}} \mathrm{C} \text { e enf }{ }^{\mathrm{a}} \mathrm{D}-24 \text { aos } 65 \\
\text { anos }\end{array}$ \\
\hline & $\begin{array}{l}\text { Outubro } 2009 \\
\text { /October } 2009\end{array}$ & Interview inference enf $f^{a} Z /$ Entrevista de inferência enf ${ }^{a} Z$ \\
\hline
\end{tabular}


Data triangulation was made through diversification of sources of origin (nurse and elderly person) and different actions (visits, consultations, group actions, etc.). Several data collection techniques were selected (formal and informal interviews and participant observation). Table 1 describes the process of data collection. Step 3 - The results of the initial and free observation and findings from this preliminary study allowed the construction of observation and interview guidelines.

Step 4 - The data gathering and analysis began to be carried out more intensively. After the first open codifications and axial codification took place, informal interviews to ascertain the properties and conceptual dimensions and the sense explained by the first diagrammatic tests occurred. Interviews, semi-structured and programmed in depth, were conducted and programmed in depth for the elderly and the nurses during selective coding. The central concept was found, and it was necessary to obtain assurance that they were inter-related with all the categories which emerged. Open and axial coding was then repeated when new data was added. Data collection was completed with the nurse inference interview.

For observation recording, field notes, reminders, journals and memos were made. The links between subcategories, categories and core concept were visualized by diagrams. Formal interviews were audio recorded and transcribed. The informal interviews followed the same strategy of observation.

Consistent with the method grounded theory, the constant data comparison analysis took place simultaneous to its systematic collection, following the guidelines of Corbin and Strauss. ${ }^{(1)}$ The Nvivo7 program was used. Words and text segments, which were examined and compared between them, were dissociated: similarities and differences were captured. We identified concepts, including their properties and dimensions. It is described under what circumstances nurse and elderly person interact between them and each one with himself and with the environment, the strategies that people adopt in their actions and the consequences or results of the whole process of interaction.

Internal validation was conducted with the subjects and externally with the experts. This external judges not only certified the stability of categorization emerged as confirmed this consistency in the theoretical explanation of the phenomena studied.

All ethical procedures, requesting authorizations for data collection to the appropriate organizations and informed consent to the participants, were fulfilled.
Foi efetuada triangulação de dados: diversificação da proveniência de fontes (enfermeiro e pessoa idosa); diferentes ações (visitas, consultas, ações em grupo...). Também foram selecionadas várias técnicas de recolha de dados (entrevistas formais e informais e observação participante). A tabela 1 descreve o processo de recolha de dados.

$3^{\text {a }}$ etapa - Os resultados da observação inicial e livre e achados obtidos no estudo preliminar, possibilitaram a construção dos guiões de observação e de entrevista.

$4^{\mathrm{a}}$ etapa - A recolha e análise passou a ser efetuada de forma intensa. Após as primeiras codificações abertas e início da codificação axial decorreram entrevistas informais para certificarem as propriedades e dimensões conceptuais e o sentido explicado pelos primeiros ensaios diagramáticos. Foram efetuadas entrevistas programadas semiestruturadas e em profundidade a pessoas idosas e a enfermeiros aquando codificação seletiva. $\mathrm{O}$ conceito central foi encontrado e era necessário obter a garantia que se inter-relacionava com todas as categorias emergidas. Voltou-se à codificação aberta e axial sempre que se adicionavam novos dados. A recolha de dados foi completada com entrevista de inferência a enfermeira.

Para registo da observação criaram-se notas de campo, lembretes, diários e memos. As ligações entre subcategorias, categorias e conceito central eram visualizadas através de diagramas. As entrevistas formais foram áudio gravadas e transcritas. As informais seguiram a mesma estratégia da observação.

Fidelizados ao método grounded theory, a análise comparativa constante de dados decorreu em simultâneo com a sua recolha sistemática, seguindo as orientações de Corbin e Strauss ${ }^{(1)}$, e utilizando o programa Nvivo7. Dissociaram-se palavras, segmentos de texto, os quais foram examinados e comparados entre si: captaram-se similaridades e diferenças. Identificámos conceitos, as suas propriedades e dimensões. Descreveram-se em que circunstâncias enfermeiro e pessoa idosa interagem entre si e cada um consigo próprio e com o meio, as estratégias que as pessoas adotam no seu agir e as consequências ou resultados de todo este processo de interação.

Foi realizada validação interna junto dos sujeitos e externa junto de peritos. Estes juízes externos não só certificaram a estabilidade da categorização emergida como confirmaram a consistência presente na explicação teórica do fenómeno estudado.

Cumpriram-se todos os procedimentos éticos, solicitando autorização para a recolha de dados às Organizações e consentimento informado aos participantes. 


\section{Results}

The use of the grounded theory ${ }^{(1)}$ analysis method and other methodological decisions described resulted in the emergence of the middle-range theory, which explains the interaction process of elderly person-nurse in successful aging and in primary health care setting.

The new theory taxonomically presents the aesthetic, ethical and personal/individual standards. Aesthetic standards, because the elderly person-nurse interaction was perceived as a creative and expressive art from which emerge human actions that result in behaviors evidenced uniquely by each individual. Ethical standards, because captured in all the interaction was the moral duty transmitted by symbolic representations which reveal the decision making inherent in the journey of life experienced by the elderly and accompanied by the nurse. Personal/individual standards, because it distinguishes the relationship between nurse and elderly. This relationship does not come exclusively from formal learning in nursing but from the intrinsic personal characteristics of the nurse himself/herself. An individual domain is evidenced which demonstrates the integrity meeting of the elderly person-nurse underlying the presence of self-awareness and active empathy. In this way the involvement and intuition of the action can be empirically explained, valuing it and clarifying it in an authentic and genuine way, directly from the data.

As for the stage of knowledge of development, the theory falls within the integration domain not only because there is at its core specific areas of nursing, primary health care and gerontology, as well as a valorization process of the areas of education, research and of the practice in a continuous evolution of knowledge. The interdisciplinary nature is also clear. The research conducted advocates a close relationship between researcher and nurse of clinical practice, favoring the development of nursing knowledge and impacting education areas.

\section{Discussion}

Nursing is a human science and an art that seeks to monitor the individual on its life journey. The elderly person-nurse interaction in successful aging context in primary health care settings was a phenomenon to understand and explain, the choice of grounded theory seconds Corbin and Strauss ${ }^{(1)}$ and facilitated the response to the question and formulated its defined goals, primarily because the phenomenon under study covers

\section{Resultados}

A utilização do método de análise grounded theory ${ }^{(1)}$ e restantes decisões metodológicas descritas fizeram emergir a teoria de médio-alcance explicativa do processo de interação enfermeiro-pessoa idosa no âmbito de envelhecimento bem-sucedido e em ambiente de cuidados de saúde primários.

A nova teoria apresenta taxonomicamente os padrões estético, ético e pessoal/individual. Padrão estético porque a interação enfermeiro-pessoa idosa, foi percebida como uma arte criadora e expressiva de onde emergem ações humanas que resultam em comportamentos evidenciados por cada ser individual e único. Padrão ético, porque em toda a interacção foi captado o dever moral transmitido por representações simbólicas que relevam a tomada de decisão inerente ao percurso de vida experienciado pela pessoa idosa e acompanhado pelo enfermeiro. Padrão pessoal/individual, por se distinguir a relação estabelecida entre enfermeiro e pessoa idosa. Esta relação não advém em exclusivo da aprendizagem formal em enfermagem mas às características pessoais intrínsecas do próprio enfermeiro. Evidencia-se um domínio individual que patenteia a integridade do encontro enfermeiro-pessoa idosa subjacente à presença de autoconsciência e empatia ativa. Neste sentido explica-se empiricamente o envolvimento e intuição da ação valorizando-a e clarificando-a de forma autêntica e genuína, ou seja a partir diretamente dos dados.

Quanto ao estádio do desenvolvimento do conhecimento, a teoria enquadra-se no domínio da integração não só porque há core em áreas específicas da enfermagem: cuidados de saúde primários e gerontologia, como também um processo de valorização das áreas da educação, da investigação e da prática numa contínua evolução do conhecimento. Também está patente o estádio da interdisciplinaridade. A investigação desenvolvida preconiza uma relação próxima entre investigador e enfermeiro da prática clínica favorecendo a evolução do conhecimento em enfermagem com repercussões na área da educação.

\section{Discussão}

Sendo a enfermagem uma ciência humana e uma arte que procura acompanhar o indivíduo no seu percurso de vida, e se a interação enfermeiro-pessoa idosa em contexto de envelhecimento bem-sucedido e em ambiente de cuidados de saúde primários era um fenómeno por compreender e explicar, a opção pela grounded theory segundo Corbin e Strauss ${ }^{(1)}$ facilitou a obtenção da resposta à pergunta de investigação formulada e aos 
a process ${ }^{(1,19,20,21,22,23,24,25)}$.

Choosing a qualitative paradigm facilitated the study of the phenomenon. Human behavior while during interactions requires relativity and abstraction, and nursing includes actions not always easily visible, going beyond manageable tasks. So the research was guided by the discovery in order to search for meanings and explanations. Watson ${ }^{(27)}$ states that discovering and searching leads to the development of science as a continuous and progressive process. This was the case: finding and searching the life experiences of the elderly as of the participating nurses in the research as actors in a process of interaction. The grounded theory responded to the concerns because not only did it favor clarifying feelings, thoughts, and emotions, but also helped to realize them in interactional situations.

If man is an unfinished being, in a state of continuous development and of an unquestionable individuality, ${ }^{(28)}$ and if studied in a process of interaction, there is a dynamic in space and single time dimension that leads to his capture and perception in an inductive form ${ }^{(15,29,30)}$. Therefore the initiation of study of inductive reasoning is relevent. Following Morse ${ }^{(29,30)}$, this inductive method of research is consistent with the heritage and tradition of nursing, and so is consistent with human science and care, offering a reliable consciousness.

As recommended by Charmaz ${ }^{(31)}$, Lopes ${ }^{(16)}$, Ribeiro ${ }^{(32)}$, and Turato ${ }^{(33)}$ the phenomenon was studied in its natural setting, interpreting it in terms of the meanings that events have on participants. The search therefore is naturalistic.

Epistemologically arguing strictly the qualitative research as an autonomous path of knowledge production could lead to some vulnerability, ${ }^{(34)}$ therefore the data triangulation guaranteed heuristic rigor of the pro$\operatorname{cess}^{(1,35,67,37,16)}$. Data was collected in different dates, locations, and in different people (see Table I).

The theoretical sampling made it possible to answer the theoretical object as confirmed by different authors ${ }^{(31,1,36)}$. All participants who were integrating in the study gave wealth of content, through their reports, or through interactions that they staged.

Following scripts of observation and interview, as is advocated by several authors ${ }^{(5)}$, secured a strict protocol for data collection.

The participant observation is the data collection technique that gathers a prominent place in qualitative re$\operatorname{search}^{(37,36,16,34)}$ and in fact allowed access to the social world experienced by the actors in the events that were occurring: it was possible to understand the interaction during the course of events. Besides the finding of objective elements as procedures, times and places, it also clarified senses, dynamics and processes of the acts, objetivos definidos. E principalmente porque o fenómeno em estudo encela um processo ${ }^{(1,19,20,21,22,23,24,25)}$.

Enveredar-se por um paradigma qualitativo facilitou o estudo do fenómeno. O comportamento humano enquanto interação exige relatividade e abstração e a enfermagem integra ações nem sempre facilmente visíveis, indo para além de tarefas exequíveis. Assim a investigação foi orientada pela descoberta com o fim de procurar significados e obter explicações. Watson ${ }^{(27)}$ refere que descobrir e procurar conduz à evolução da ciência como um processo contínuo e progressivo. E foi isso que aconteceu: descobrir e procurar as experiências vividas quer dos idosos, quer dos enfermeiros participantes na investigação enquanto atores num processo de interação. A grounded theory respondeu às inquietações porque não só favoreceu o tornar claro sentimentos, pensamentos e emoções como ajudou a percebe-los em situações interacionais.

Se o homem é um ser inacabado, num contínuo desenvolvimento e de uma individualidade inquestionável (28) e se estudado num processo de interação, há uma dinâmica no espaço e uma dimensão temporal que conduz à sua captação e perceção de forma indutiva ${ }^{(15,29,30)}$. Certificou-se assim a pertinência de se enveredar por um estudo de raciocínio indutivo. Seguindo Morse ${ }^{(29,30)}$, este modo indutivo de pesquisar está de acordo com a herança e tradição da enfermagem, ou seja, está congruente com a ciência humana e o cuidado, o que oferece uma consciência de confiança.

Tal como é preconizado por Charmaz ${ }^{(31)}$, Lopes ${ }^{(16)}$, Ribeiro $^{(32)}$, e Turato ${ }^{(33)}$ estudou-se o fenómeno no seu setting natural interpretando-o a nível dos significados que os acontecimentos têm para os participantes. Daí, confirmar-se que a pesquisa é naturalista.

Epistemologicamente argumentar a investigação estritamente qualitativa, como percurso autónomo da produção de conhecimento, poderia susceptibilizar alguma vulnerabilidade ${ }^{(34)}$ pelo que a triangulação de dados garantiu o rigor heurístico do processo ${ }^{(1,35,67,37,16)}$. Recolheram-se dados em datas, locais e em pessoas diferentes (ver Tabela I).

A amostragem teórica tornou possível a resposta ao objeto teórico como confirmam diferentes autores ${ }^{(31,1,36)}$. Todos os participantes que se foram integrando no estudo forneceram riqueza de conteúdo, quer através dos seus relatos, quer através das interações que protagonizaram.

Seguir guiões de observação e de entrevista, conforme é defendido por diversos autores ${ }^{(5)}$, assegurou um protocolo rigoroso de recolha de dados.

A observação participante é a técnica de recolha de dados que ganha lugar de destaque na investigação qualitativa ${ }^{(37,36,16,34)}$ e de facto permitiu o acesso ao mundo 
therefore being a naturalistic observation ${ }^{(5)}$. This technique being in accordance with the current symbolic interaction, made the elderly person-nurse interaction perceived as a theatrical scene. Lopes ${ }^{(16)}$ named the observation of non-participant in the process of studying the relationship between nurse and patient. In this study we considered the participant observation: consciously there was no interference in the process of interaction but only the fact that the actors captured the investigator by the senses while acting makes the observation considered as a participant.

Like De la Cuesta ${ }^{(38)}$, informal interviews arose from the fieldwork as natural consequence of the participant observation: they were carried out as momentary and spontaneous needs to of completing and understanding data obtained by the observation came up. The programmed interviews were semi-structured, and therefore, in some depth proved to construct a fundamental data collection technique referred to as qualitative studies by the authors ${ }^{(37,39,40,36,34,16)}$. The various documents and records used suggested by the authors ${ }^{(5,36,31,1)}$, facilitated the arrival of the phenomenon under study explanation. The diagrams promoted the analog representation of the theoretical construct emerged.

Following the guidelines of Corbin and Strauss ${ }^{(1)}$, the open codification, axial and selective codification were made possible. This was a key step for the understanding and explanation of the phenomenon under study. Different authors ${ }^{(31,1,23,16,25)}$ refer to that phenomena, such as events and actions that may be similar in their nature or related in meaning, as grouped under concepts. The analysis was tested to be free of preexisting concepts, however, the findings obtained in the exploratory phase of research facilitated the identification of the tracks of axial and selective codification.

The use of the Nvivo $7^{(41)}$ program established a simple data manipulation strategy . Relatively quickly, it made it possible to follow the pathway of analysis as of full texts, selected parts, coded and grouped, and associated memos, By viewing at a more advanced stage, diagrams consisting of the subcategories and categories emerged. The information obtained by inference interview confirmed perceived ideas. It was an asset to known meanings attributed to the phenomenon through non-participant nurse.

Internal validation of the findings ensured the accuracy and reliability of the emerged construct and made it possible to fill gaps between the information obtained. As to the external, the judges not only certified the stability of the emerged categorization, but also confirmed the consistency in the theoretical explanation of the phenomena studied.

The fact that we omitted participants and locations social experienciado pelos atores nos acontecimentos que iam decorrendo: conseguiu-se compreender a interação no decurso dos eventos. Para além da captação de elementos objetivos como procedimentos, tempos e lugares, também clarificou sentidos, dinâmicas e processos dos atos, por isso ser uma observação naturalista ${ }^{(5)}$. Esta técnica ao estar em concordância com a corrente do interacionismo simbólico, tornou a interação enfermeiro-pessoa idosa percebida como uma cena teatral. Lopes $^{(16)}$ nomeou a observação de não participante no seu estudo de processo de relação entre enfermeiro e pessoa doente. Nesta investigação considerou-se a observação participante: conscientemente não se interferiu no processo de interação mas só o facto de os atores terem captado o investigador pelos sentidos enquanto atuavam faz considerar a observação como participante.

À semelhança de De la Cuesta ${ }^{(38)}$, as entrevistas informais foram decorrentes do trabalho de campo, consequência natural da observação participante: eram realizadas à medida que iam surgindo necessidades momentâneas e espontâneas de completar e perceber dados captados pela observação. As entrevistas programadas, semiestruturadas, e por isso, algumas em profundidade, comprovaram constituir uma técnica de recolha de dados fundamental em estudos qualitativos como é referido pelos autores ${ }^{(37,39,40,36,34,16)}$. Os vários documentos de registos utlizados e sugeridos pelos autores ${ }^{(5,36,31,1)}$, facilitaram a chegada à explicação do fenómeno em estudo. Os diagramas promoveram a representação analógica do constructo teórico emergido.

Seguir as orientações de Corbin e Strauss ${ }^{(1)}$, tornou possível a codificação aberta, codificação axial e seletiva. Foi uma etapa fulcral para a compreensão e explicação do fenómeno em estudo. Diferentes autores ${ }^{(31,1,23,16,25)}$, referem que fenómenos tais como eventos e ações, que possam ser semelhantes na sua natureza ou relacionados no seu significado são agrupados sob conceitos. Tentou-se que a análise fosse livre de conceitos preexistentes contudo os achados obtidos na fase exploratória da investigação facilitaram a identificação dos trilhos da codificação axial e seletiva.

A utilização do programa Nvivo $7^{(41)}$ constituiu uma estratégia de manipulação simples de dados. Com alguma rapidez se conseguia seguir o percurso de análise quer textos integrais, excertos selecionados, codificados e agrupados, memos associados, visualizando em fase mais avançada, diagramas constituídos pelas subcategorias e categorias emergidas.

A informação obtida por entrevista de inferência certificou ideias percecionadas. Foi uma mais-valia, ter-se conhecido significados atribuídos ao fenómeno através de enfermeira não participante.

A validação interna dos achados assegurou a veracidade 
where the interactions took place ensured the confidentiality and privacy of each subject. "Primacy of the human being" ${ }^{(42)}$ was the ethical principle always present at all stages of research, establishing the scientific interest and the subject well-being in harmony and parsimony between society and science.

The aesthetic standards, ethical and individual/personal, reflect the taxonomy shown by Carper ${ }^{(43)}$. The development stage of knowledge identified followed the theoretical reasoning of Meleis ${ }^{(3)}$.

\section{Conclusion}

The middle-range theory, which emerged from the grounded theory analysis method, became an explanatory model for nursing practice in primary health care in relation to the process of elderly person-nurse interaction and of the successful aging.

It is a theory in which taxonomically aesthetic standards, both ethical and personal/individual, prevail. Regarding the development of knowledge, it fits the domain of integration and also the interdisciplinary stadium.

At this time the theory is being tested in a hospital environment. In the future we intend to extend the research to processes of interaction between nurses and people to experience other specifics life stages, such as maternity, child development and vital evolution in the young adult stage.

It is expected that the clarification of the life experience, reflected in the central concept, becomes regular in the different circumstances experienced by the person as an actor of his effective social interactions and interaction with the nurse.

\section{Acknowledgements}

To all the nurses and volunteers who agreed to participate in the study.

\section{Conflict of interest}

The author states that there are no financial or personal relationships that might be perceived as potential conflict of interests. e fiabilidade do constructo emergido e permitiu preencher lacunas entre a informação obtida. Quanto à externa, os juízes não só certificaram a estabilidade da categorização emergida como confirmaram a consistência presente na explicação teórica do fenómeno estudado.

Ter-se ocultado participantes e espaços onde as interações decorreram assegurou a confidencialidade e privacidade de cada sujeito. "Primado do ser humano"(42) foi o princípio ético sempre presente em todas as etapas da investigação, consagrando o interesse científico e o bem-estar do sujeito numa harmonia e parcimónia entre sociedade e ciência.

Os padrões estético, ético e indivudual/pessoal encontrados refletem a taxonomia apresentada por $\operatorname{Carper}^{(43)}$. O estádio do desenvolvimento do conhecimento identificado segue o raciocínio teórico de Meleis ${ }^{(3)}$.

\section{Conclusão}

A teoria de médio-alcance emergida do método de análise grounded theory tornou-se um modelo explicativo para a prática de enfermagem em cuidados de saúde primários no que se refere ao processo de interação enfermeiro-pessoa idosa e no âmbito do envelhecimento bem-sucedido.

É uma teoria onde prevalecem taxonomicamente os padrões estético, ético e pessoal/individual. Ao nível do desenvolvimento do conhecimento enquadra-se no domínio integração e igualmente no estádio da interdisciplinaridade Neste momento a teoria está a ser testada em contexto hospitalar. No futuro pretende-se estender a investigação a processos de interação entre enfermeiro e pessoas a experienciarem outras especificidades do vivido, como maternidade, desenvolvimento infantil e evolução vital na etapa de adulto jovem.

Expecta-se que a clarificação da experiência de vida, patente no conceito central, seja uma regularidade nas diferentes circunstâncias vividas pela pessoa enquanto ator dos seus processos sociais e em interação com o enfermeiro.

\section{Agradecimentos}

A todos os enfermeiros e voluntários que aceitaram participar no estudo.

\section{Conflito de interesses}

A autora declara que não existem relações financeiras ou pessoais que puderam ser vistas como um potencial conflito de interesses. 


\section{References/ Referências}

[1] Corbin, J. \& Strauss, A. Basics of Qualitative Research, 3rd ed. Los Angeles: Sage, 2008.

[2] McKenna, H. (1997). Nursing Theories and Models. London: Routledge.

[3] Meleis, A. theorical nursing: Devlopmente and progress, 4th ed. Philadelphia: Lippincott Williams \& Wilkins, 2007.

[4] Polit, D. \& Beck, C. Nursing Research: Principles and Methods. 7th ed. Philadelphia: Lippicott Williams \& Wilkins, 2004.

[5] Polit, D., Beck, C. \& Hungler, B. Search Fundamentals of Nursing: Methods, evaluation and utilization 5th ed. London: Artmed 2004. (Original work published in 2001 in English; translation Thorell, A., Light review, A.).

[6] Roy, C. \& Jones, D. Nursing Knowledge Development and Clinical Practice. New York: Springer Publishing Company, 2007.

[7] Smith, M. \& Liehr, P. Midle Range Theory for Nursing, 2nd ed. New York: Springer Publishing Company, 2008

[8] Laudan, Il progrsso cientigico. Prospective per una theory. Rome: Armando, 1979.

[9] Merton, R. Sociology Theory and Structure. São Paulo: Editora Master jov, 1970.

[10] Im, E-O. Development of Situation-specific Theories: An Integrative Approach. Advances in Nursing Science, 2005; 28 (2), 137-151.

[11] Flood, M. The Mid-Range Nursing Theory of Successful Aging. The Journal Of Construction \& Testing Theory 2006; 9 (2), 35 39.

[12] Fernandes, M. Successful aging - the nurseaged person interaction process in primary health care, 2013; 10 (2), 151-162.

[13] Fernandes, M. Successful aging - of nursing intervention model. In: Lopes, M. Nursing care for the elderly - From research to practice. Loures: Lusociência; 2013.p.3-37.

[14] Wadensten, B. \& Carlsson, M. Theory-driven guidelines for pratical care of older people, based on the theory of gerotranscendence. Journal of Advanced Nursing 2002, 41 (5), 462-470

[15] Strains, P. Care End of Life: Factors that interfere in the nurse patient interaction process. Referência, 2006; 4 (II), 35-60.

[16] Lopes, M. The nurse-patient relationship as a therapeutic intervention. Coimbra: Formasau 2006.

[17] Veiga, M. Protecting the identity of the elderly in hospital: A nursing challenge. $\mathrm{PhD}$ Thesis. Port: University of Porto, Abel Salazar Institute of Sciences, 2007.
[18] Fernandes, M. Report development of $\mathrm{PhD}$ project. Lisbon: Portuguese Catholic University, 2008

[19] Cutcliffe, J. Adapt or adopt: Developing and transgressing the methodological boundaries of grounded theory. Journal of Advanced Nursing, 2005; 51 (4), 421-428.

[20] Eaves, I. The synthesis technique is grounded theory data analysis. Journal of Advanced Nursing, 2001; 35 (5), 654-663.

[21] Jeon, Y-H. The application of grounded theory and symbolic Interactionism. Scandinav Caring Science Journal, 2004; 18, 248-256.

[22] Kinach, B. Grounded Theory the Scientific Method: Haig-Inspired Reflections on Educational Methodology. Philosophy of Education, 1995. Retrieved on 2006, May $2 \mathrm{http} / / /$ www.ed.uiuc.edu/EPS/PES-yearbook/95_ docs/kinach.html

[23] Lopes, M., The methodology of Grounded Theory. A contribution to the conceptualization of nursing. Journal of Nursing Research. 2003; August 63-74

[24] Mills, J., Chapman, Y., Bonner, A., \& Francis, K. Grounded theory: The methodological spiral from positivism to postmodernism. Journal of Advanced Nursing, 2007; 58 (1), 72-79.

[25] Pandit, N. The creation of Theory: A Recent Application of the Grounded Theory Method. The Qualitative Report, 1996; December: 2 (4)

[26] Haig, B. Theory Grunded the Scientific Method. Philosophy of Education, 1995. Retrieved on 2006, May $2 \mathrm{http} / / / w w w . e d . u i u c$. edu/EPS/PES-yearbook/95 _ docs / haig. $\mathrm{html}$

[27] Watson, J. Postmodern Nursing and future: a new paradigm of nursing. Camarate: $\mathrm{Lu}-$ sociência, 2002. (Original work published in 1999 in English; translation Enes, J., scientific review Novais technique, E.)

[28] Tomey, A. \& Alligood, M. Theoretical Nursing and His Work. 5th ed. Loures: Lusociência; 2004.

[29] Morse, J. The Nature of Qualitative Evidence. London: Sage, 2001.

[30] Morse, J. Qualitative Research Methodology. Coimbra: Formasau, 2007. (Original work published in English in 1994; Sword translation, A.)
[31] Charmaz, K. Constructing Grounded Theory: A Practical Guide through Qualitative Analysis. London: Sage, 2006.

[32] Ribeiro, J. Methodology of Research in Psychology and Health. Porto: Livpsic, 2007.

[33] Turato, E. qualitative and quantitative methods in health: definitions, differences and research objects. Journal of Public Health, 2005; 39 (3), 507-514.

[34] Lessard-Hébert, M., Goyette, G. \& Boutin, G. Qualitative Research: Principles and Practices. 3rd ed. Lisbon: Instituto Piaget, 2008. (Original work published in French in 1990; translation of Kings, M.)

[35] Denzin, NK The Research Act: A theorical introdution to sociological methods, 3th ed. Englewood Cliffs, NJ: Prentice Hall, 1989.

[36] Flick, U. Qualitative Methods in Scientific Research: Lisbon: Monitor, 2005. (Original work published in English in 2002; translation heck, A.)

[37] Costa, A. Care Elderly: Training, practice and skills of nurses. Lisbon: Formasau 2002.

[38] De la Cuesta, C. El investigator as flexible instrument it indagación. International Journal of Qualitative Methods, 2003; Jul 2 (4). Refurbished in 2009 April 1 http://www. ualberta.ca/ iiqm/backissues/2_4/pdf/delacuesta.pdf.

[39] De la Cuesta, C. Strategies but used en el campo de la salud. Investigación Nure, 25 2006. Retrieved on 2009 April 1, http: // www. Nureinvestigacion. es / ficheros ADMINISTRATOR / F methodological / Fmetod 25.pdf

[40] De la Cuesta, C. Grounded Theory: Un product y una strategy to analyze cualitativos datos. Workshop organized by the Office of Research and Development in Nursing in 2009, April 16. Lisbon: Lisbon University.

[41] QSR International Pty Lda NVivo7: the introductory tutorials 2006. http: // download. Qsrinternational.com/Document/NVivo7/ NVivo7_Tutorials_Lyn_Richards.pdf

[42] Silva, MP Biomedical Research: Ethical Reflections. Lisbon: Gradiva, 2008.

[43] Carper, B. Fundamental patters of Knowing in nursing. Advances in Nursing Science 1978; 1 (1), 13-23. 